\title{
P235: Incidence of nosocomial infection in long term institution and control measures
}

\author{
ACDS Oliveira*, S Scota, I França, AM Costa e Silva \\ From 2nd International Conference on Prevention and Infection Control (ICPIC 2013) \\ Geneva, Switzerland. 25-28 June 2013
}

\section{Introduction}

The Premier Hospital specializes in the care of chronic patients with high dependency, especially elderly patients with chronic and degenerative diseases. It has 80 beds, with three units, one unit of semi-intensive care, emergency treatment and outpatient. Infections in the elderly are a major cause of morbidity, hospitalization and mortality and it is difficult to approach and diagnosis.

\section{Objective}

To evaluate the rate of urinary tract infection in the institution after training the employees.

\section{Method}

Data were collected from January to December 2012, the Commission of Infection Control. As the Brazilian statistics are under construction, we used for comparison, data from international incidence of infection/ patient-days. Conducted training and guidance on hand hygiene and technique of bladder catheterization for employees of the institution.

\section{Results}

Infection rates in 2011: Fee general Hospital Infection 8.73 infections $/ 1000$ patient-days and rate of urinary tract infection 3.35 infections/1000 patient-days. Infection rates in 2012: Fee general Hospital Infection 6.70 infections/1000 patient-days and rate of urinary tract infection: 2.37 infections/1000 patient-days.

\section{Discussion}

It was established control measures to prevent Urinary Tract Infection. Held careful evaluation of the need for catheterization, training of nursing staff regarding the

Educação Continuada e CClH, Instituto de Infectologia Emílio Ribas, São Paulo, Brazil passage of the probe technique and care in maintenance, which also included simple precautions like using container unique to each patient to despise the urine. With these interventions decreased the rate of 3.35 infections/ 1000 Urinary Tract Infection patient-days in 2011 to 2.37 infections/1000 patient-days in 2012, achieving the value of international incidence data.

\section{Conclusion}

We believe that training with continuous care in the insertion/maintenance and careful evaluation for catheterization, will achieve even lower rates of infection.

\section{Disclosure of interest}

None declared.

Published: 20 June 2013

doi:10.1186/2047-2994-2-S1-P235

Cite this article as: Oliveira et al.: P235: Incidence of nosocomial infection in long term institution and control measures. Antimicrobial Resistance and Infection Control 2013 2(Suppl 1):P235.

Submit your next manuscript to BioMed Central and take full advantage of:

- Convenient online submission

- Thorough peer review

- No space constraints or color figure charges

- Immediate publication on acceptance

- Inclusion in PubMed, CAS, Scopus and Google Scholar

- Research which is freely available for redistribution 